\title{
PCDD/F and Dioxin-Like PCB Determinations in Mtoni Estuarine Sediments (Tanzania) Using the Chemically Activated Luciferase Gene Expression (CALUX) Bioassay
}

\author{
Matobola J. Mihale ${ }^{1,2}$, Kim Croes $^{1}$, Clavery Tungaraza ${ }^{3}$, Willy Baeyens ${ }^{1} \&$ Kersten Van Langenhove $^{1}$ \\ ${ }^{1}$ Department of Analytical and Environmental Chemistry, Vrije Universiteit Brussel (VUB), Pleinlaan, Brussels, \\ Belgium \\ ${ }^{2}$ Department of Physical Sciences, Open University of Tanzania (OUT), Dar es Salaam, Tanzania \\ ${ }^{3}$ Department of Physical Sciences, Sokoine University of Agriculture (SUA), Chuo Kikuu Morogoro, Tanzania \\ Correspondence: Kersten Van Langenhove, Department of Analytical and Environmental Chemistry, Vrije \\ Universiteit Brussel (VUB), Pleinlaan 2, Brussels 1050, Belgium. Tel: 32-26-293-293. E-mail: \\ kavlange@vub.ac.be
}

Received: February 18, 2013 Accepted: March 19, 2013 Online Published: May 2, 2013

doi:10.5539/ep.v2n3p1 URL: http://dx.doi.org/10.5539/ep.v2n3p1

\begin{abstract}
Sediments from Mtoni estuary and 2 tributaries, Tanzania, were screened for polychlorinated- $p$-dibenzodioxins, -dibenzofurans (PCDD/Fs) and dioxin-like PCBs (dl-PCBs) using the chemically activated luciferase gene expression (CALUX) bioassay approach. PCDD/Fs expressed as bio analytical equivalence (BEQ) values ranged from $5.7 \pm 1.4$ to $39.9 \pm 5.8 \mathrm{pg} \mathrm{BEQ} / \mathrm{g}$ sediment in the wet season and from $14.1 \pm 2.0$ to $32.8 \pm 4.7 \mathrm{pg} \mathrm{BEQ} / \mathrm{g}$ sediment in the dry season, with higher levels observed in Kizinga River and stations close to the mouth of that river. Dioxin-like PCB levels ranged from $0.21 \pm 0.03$ to $0.53 \pm 0.03 \mathrm{pg} \mathrm{BEQ} / \mathrm{g}$ sediment in the wet season and from $0.22 \pm 0.03$ to $0.59 \pm 0.04 \mathrm{pg} \mathrm{BEQ} / \mathrm{g}$ sediment in the dry season. Higher PCDD/F and dl-PCB levels in sediments are probably related to open burning of plastic scraps, household burning of wood or charcoal and traffic related emissions, all of which occur in the Dar es Salaam region. The denser population and the more intense industrial activities in the Kizinga River basin may explain the enhanced PCDD/F and dl-PCB levels observed in the sediments of that river compared to the levels in the Mzinga River basin. A third sampling campaign, including also stations in the downstream estuary, confirmed the enhanced levels in the Kizinga River (maximum of $400 \mathrm{pg}-\mathrm{BEQ} / \mathrm{g}$ ) and also showed that a clear decreasing concentration gradient in the downstream direction exists. It cannot be excluded that the levels of these pollutants in the sediments of the Mtoni estuary pose a threat to the local biological community.
\end{abstract}

Keywords: PCDD/Fs, Dioxin-like PCBs, sediment, Mtoni Estuary, Tanzania, CALUX Bioassay, ecological risk

\section{Introduction}

Polychlorinated dibenzo- $p$-dioxins and polychlorinated dibenzofurans, which are collectively referred to as PCDD/Fs, have no commercial use and occur in the environment as unintended by-products of technological processes (Pan et al., 2010; Roots, Henkelmann, \& Schramm, 2004). PCDD/Fs can be formed from natural combustion processes like bushfires and volcanoes (Birch, Harrington, Symons, \& Hunt, 2007) or during incomplete anthropogenic combustion processes of chlorinated organic wastes such as for example incineration of polyvinyl chloride plastics (Birch et al., 2007; Terauchi, Takahashi, Lam, Min, \& Tanabe, 2009). Formation of dioxins in such incinerators occurs due to the presence of both chlorine and catalytic metals (Manahan, 2008). Industrial activities such as metallurgy and manufacture of chlorinated chemicals, like wood preservatives and pesticides, can also produce dioxins (El-Kady et al., 2007; Ryoo et al., 2005).

Polychlorinated biphenyls (PCBs) were once produced commercially (Koistinen, Stenman, Haahti, Suonper, \& Paasivirta, 1997; Srogi, 2007) and used in industrial and consumer products (Liu et al., 2006; Wang et al., 2007), such as anti-corrosion materials, coolants and insulators in heat transfer systems, electronic appliances and hydraulic fluids (Shen et al., 2009; Yang, Shen, Gao, Tang, \& Niu, 2009) and as capacitors in electrical industries (Pan et al., 2010). Common PCB sources in the environment include the use as well as disposal of PCB-containing products and the formation of PCBs as by-products at low temperature (less than $800{ }^{\circ} \mathrm{C}$ ) waste 
incineration (Chi, Chang, \& Kao, 2007). Twelve of these PCBs have a planar structure and elicit biochemical and toxic responses similar to dioxins and are therefore known as dioxin-like PCBs or dl-PCBs (Okay et al., 2009).

Both natural and anthropogenic sources can lead to increased levels of these compounds in estuaries and coastal marine ecosystems (Kumar, Sajwan, Richardson, \& Kannan, 2008). Major anthropogenic activities are linked to population growth, urbanization and industrialization (Kumar et al., 2008; Müller et al., 2002) and include effluents from municipal wastewater plants (Moon, Choi, Choi, Ok, \& Kannan, 2009), combustion processes from waste incinerators or cement manufacturing, power plants and automobile exhausts (Zhang et al., 2010) and industrial processes like pulp bleaching and metallurgy (Bruckmeier et al., 1997).

Mangrove sediments can act as sinks and later as sources of PCDD/F and PCB contaminants to marine environments (Chi et al., 2007; Guzzella et al., 2005; Müller et al., 1999). Hence, sediments can be used to evaluate pollutant sources, historical trends and fate processes, since the amounts of these compounds in sediments will reflect regional discharges (Lee, Kim, Chang, \& Moon, 2006; Moon et al., 2009). Contaminated sediments may therefore threaten the lives of organisms in the marine environment due to the toxicity, long time persistence, bioaccumulation and biomagnification of these lipophilic organic micro-pollutants (Kumar et al., 2008; Zhao et al., 2010).

Various analytical methods have been used to characterize PCDD/Fs and dl-PCBs in a sediment matrix. Gas chromatography-high resolution mass spectrometry (GC-HRMS) offers a possibility to chemically identify and quantify individual congeners (Besselink et al., 2004; Denison et al., 2004; Denison, Pandini, Nagy, Baldwin, \& Bonati, 2002; Schecter et al., 1999) in the matrix and to enable the assessment of risks associated with the congeners (Long et al., 2006). To estimate the risks from the GC-HRMS results it is assumed that the additivity principle of a pollutant's response or effect is valid, which means the absence of agonistic and antagonistic interactions, and that these effects are produced through the same mechanism of toxicity. However, it has been shown that complex mixtures of PCDD/F and dioxin-like PCB congeners elicit synergistic and/or antagonistic interactions (Joung, Chung, \& Sheen, 2007; Schroijen, Windal, Goeyens, \& Baeyens, 2004). In addition, chemical analysis of individual congeners, particularly in small concentrations, can be very expensive and time consuming. Presence of compounds with aryl hydrocarbon receptor (AhR) affinity, but not commonly measured, and the absence of toxicological equivalents (TEQ) for several congeners further limit the use of this analytical method (Joung et al., 2007; Long et al., 2006). To overcome some of these drawbacks, biological assays utilizing either biomolecular techniques (e.g. immunoassays) or living materials (e.g. in vitro chemically activated luciferase gene expression, CALUX) have been used as rapid and cost-effective screening methods for chemicals with selective and specific biochemical interactions (Roy, Mysior, \& Brzezinski, 2002). For example, the CALUX bioassay screens for chemicals with AhR potential (Denison et al., 2004, 2002; Schecter et al., 1999;) and produces a single integrated biological equivalent of the mixtures (Besselink et al., 2004). CALUX also measures a response which is a single toxicity end-point produced by AhR active compounds that cannot be measured and/or are below the detection level of chemo analysis (Joung et al., 2007). The major drawback of a bioassay such as CALUX is that there is no information about the congener pattern.

The CALUX method has been explained by various authors (Denison et al., 2004, 2002; Murk, 1996;). It uses genetically modified cells (hepatoma cells stably transfected with a luciferase reporter gene) which respond to chemicals that activate the cytosolar AhR by induction of luciferase (Denison et al., 2004). By this method, the toxicity of pollutants such as PCDD/Fs and dioxin like-PCBs is produced either as a change in gene expression mediated through the AhR or by interference with other pathways (Hurst, Balaam, Chan-Man, Thain, \& Thomas, 2004). Estimation of relative potency and toxic potential can therefore be done by measuring the activation level of AhR gene expression (United States Environmental protection Agency [USEPA], 2008). However, even when a rigorous clean-up and separation procedure of the sample extract is performed, interferences by $\mathrm{PCDD} / \mathrm{Fs}$ on dl-PCBs and vice versa or by other AhR ligands are still possible (Sanctorum, Elskens, \& Baeyens, 2007).

The literature regarding CALUX analyses in marine sediments is very limited. Most of the PCDD/F analyses in the world have been performed with GC-HRMS. In those studies where the CALUX technique was used, the focus was more on method development, on the comparison with the GC-HRMS method and on the screening of food and feed (Hoogenboom et al., 2006; Van Overmeire, Van Loco, Roos, Carbonnelle, \& Goeyens, 2004). In addition, very little data on dl-PCBs are available in literature. The fact is that, PCDD/F BEQ levels are in general by far higher than those of the dl-PCBs. Both chemo-analysis and CALUX analysis research on marine sediments in Africa are scarcely documented (Nieuwoudt et al., 2009; Pieters, 2007). Regarding Tanzania, only total PCBs in sediment (Machiwa, 1992) and PCDD/Fs and dl-PCBs in free range chicken have been reported (International POPs Elimination Network, 2005). 
Although there exist no data about the presence of PCDD/Fs and dl-PCBs in the environment (more specifically in the sediment) of Tanzania, the applications of PCBs in electrical transformers and in other equipment is known (Loomis, Browning, Schenck, Gregory, \& Savitz, 1997). In coastal Tanzania, there are a lot of municipal, chemical and even hospital wastes that are discharged into the Indian Ocean after incineration and open burning of mixed wastes (Machiwa, 1992). Wood burning is a common source of fuel as most households use either charcoal or firewood for cooking. In many local households, there is uncontrolled burning of plastics. Vehicle emissions are abundant due to increased traffic and importation of old, second-hand cars (Mbuligwe \& Kassenga, 1997). The current major outcry of the country has been on the vandalism of electrical transformers (Maleko, 2005) in search of their coolant for unspecified domestic or commercial use. Since Dar es Salaam is by far the largest city in Tanzania, the Mtoni estuary, being the main aquatic system in that area, was selected to study PCDD/F and dl-like PCB levels in the aquatic environment for the first time. The first objective was to assess $\mathrm{PCDD} / \mathrm{F}$ and dl-PCB levels in sediments of the mixing zone of the Mtoni estuary, including the Kizinga and Mzinga River mouths, during wet and dry seasons. A second objective was to eventually link the observed levels to local sources.

\section{Method}

\subsection{Study Area}

The Mtoni estuary (Figure 1) is located at approximately $3 \mathrm{~km}$ south of Dar es Salaam (Tanzania) and receives fresh water input from the Kizinga and Mzinga Rivers. Numerous creeks in the estuary and the river mouths host mangrove trees such as Avicennia marina, Bruguiera gymnorrhiza, Ceriops tagal, Rhizophora mucronata and Sonneratia alba species.

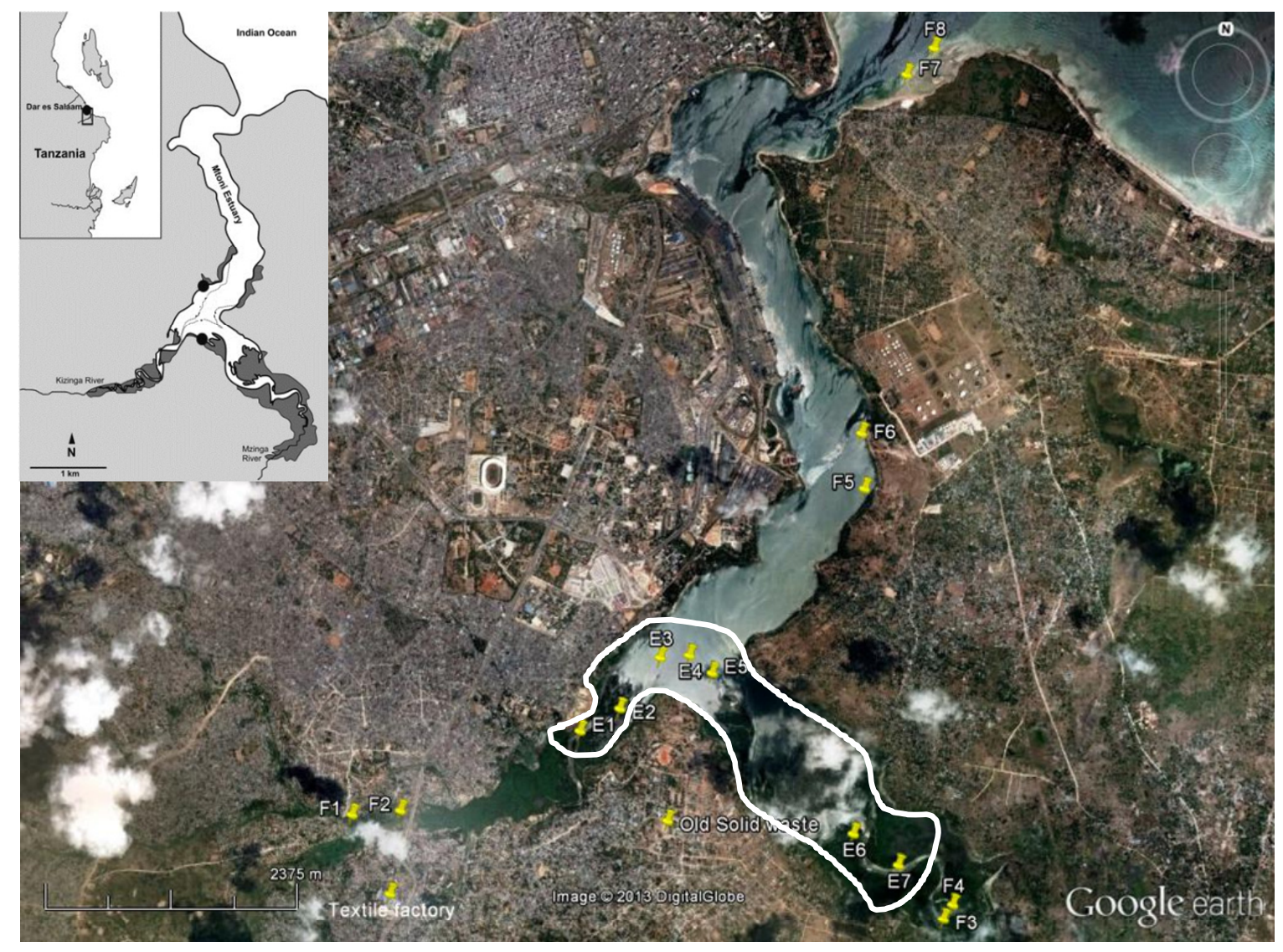

Figure 1. Sampling points in the Mtoni estuary, Dar es Salaam: E1 and E2 in the Kizinga River, E3-E5 at the confluence and E6 and E7 in the Mzinga River. Stations F1-F2 in the Kizinga River, F3-F4 in the Mzinga River, F5-F6 at the Navy shore and F7-F8 at Kigamboni Seaway are additional sampling points. White line delimits the estuarine mixing zone. The solid waste dumping site and textile factory are also indicated 
The fresh water input from both rivers is low. An average base-line flow rate of $1 \mathrm{~m}^{3} / \mathrm{s}$ is observed in Kizinga river with an increase to $8 \mathrm{~m}^{3} / \mathrm{s}$ in the rainy season while the water-flow rate of the Mzinga River is unstable and lower than in Kizinga River (Van Camp, Mjemah, Al Farrah, \& Walraevens, 2013). Hence, the effect of the river discharges on the hydrodynamics of the Mtoni estuary is very limited. The seven sampling stations (E1 to E7) are located in the mixing zone and their salinities vary from almost fresh to brackish water with somewhat higher salinities in the dry season (Kristensen et al., 2010). Downstream this mixing zone (stations F5 to F8) the water becomes rapidly sea water while the stations F1 to F4 more upstream are fresh water. This estuarine mixing zone was selected because it integrates influences of natural and anthropogenic sources in the riverine and marine systems.

The Mtoni estuary is highly impacted (Peri-urban mangrove forests as filters and potential phytoremediators of domestic sewage in east Africa [PUMPSEA], 2007) by discharges of various origin: (1) the Kizinga and Mzinga Rivers that drain the mangrove forest (Kruitwagen, Pratap, Covaci, \& Wendelaar-Bonga, 2008), (2) the wastewater drainage systems from industrial and residential areas (of a population of around 500,000 inhabitants (National Bureau for Statistics [NBS], 2003)), (3) charcoal burning, (4) mangrove harvesting for residential places, (5) salt mining, (6) tourism and (7) agriculture (Taylor, Ravilious, \& Green, 2003).

The Kizinga River that drains the urbanized areas of Keko, Chang'ombe, Kurasini and Temeke (approximately 400,000 inhabitants (NBS, 2003)) is suspected to carry a variety of wastes and discharges originating from agricultural, industrial as well as residential sources (Taylor et al., 2003). The Mzinga River, on the other hand, drains the rural areas of Vijibweni, Tuangoma and Mji Mwema with a population of around 90,000 (NBS, 2003). Due to rapid growth of settlements along the Mzinga creek resulting from increased human population, the river is suspected to carry agricultural and residential wastes and discharges presumed to be emptied into the creek. The estuary further receives inputs from the Dar es Salaam harbor which is located near the mouth of the estuary during diurnal tides (up to $5 \mathrm{~m}$ amplitude) and from the Mtoni solid waste dumping site located in between the two rivers.

\subsection{Sampling}

Sampling of sediments was conducted in the mangrove forests during low tides at Kizinga and Mzinga creeks (Figure 1) of Mtoni estuary. Two sampling campaigns were conducted: one during the wet season $\left(19^{\text {th }}-20^{\text {th }}\right.$ January, 2011) and a second during the dry season $\left(15^{\text {th }}-16^{\text {th }}\right.$ August, 2011). December and January have an average precipitation rate of 194 and $89 \mathrm{~mm}$ respectively, while these rates in July and August are much lower with 48 and $47 \mathrm{~mm}$ respectively. River flows in the Dar es Salaam area are mainly controlled by the precipitation rate in the previous period. The flows of Kizinga and Mzinga Rivers are highest in the wet season (the highest discharge rates can go up to $15 \mathrm{~m}^{3} / \mathrm{s}$ for the Kizinga River and $7 \mathrm{~m}^{3} / \mathrm{s}$ for the Mzinga River) while in the dry season, base-line flows of $1 \mathrm{~m}^{3} / \mathrm{s}$ in the Kizinga River and even lower in the Mzinga River are observed (Van Camp et al., 2013). The impact of both rivers on the pollutant levels in the mixing zone can thus best be estimated by sampling in this mixing zone at high (wet season) and at low (dry season) river flow and comparison of these results.

Samples were collected from exactly the same locations during both campaigns. Seven sampling stations were identified using a hand-held global positioning system (GPS): two in the Kizinga River (E1 and E2), two in the Mzinga River (E6 and E7) and three at the confluence of the two rivers (E3, E4 and E5).

From the results obtained during the wet and dry seasons in the mixing zone of the estuary, it appeared that the sampling stations in Kizinga River and close to its mouth showed higher PCDD/F values than the stations in and close to Mzinga River. It was thus interesting to investigate PCDD/F levels more upstream in both rivers. In addition, the salinity gradient in the mixing zone is also small and real marine water samples were not included in the previous samplings. We were thus not able to appreciate any evolution of the PCDD/F levels from the estuarine mixing zone towards the marine environment. Therefore, an additional sampling campaign was organized at 3 end-members in October 2012: (1) one site in the Kizinga River (fresh water stations F1-F2) much more upstream than stations E1 and E2, (2) one site in Mzinga River (fresh water stations F3-F4 are slightly more upstream than stations E6 and E7, but these latter stations were yet, compared to the stations E1 and E2 in Kizinga River, much more upstream) and (3) two sites in the marine area, close to and at the mouth of the estuary (respectively marine water stations F5-F6 and F7-F8) (Figure 1).

All those samples were taken from two sub-sites within a distance of $20 \mathrm{~m}$, except in the Kizinga River. The first subsample was taken at the junction of the river and the textile wastewater stream (Figure 1) and the second was taken $200 \mathrm{~m}$ upstream of the river very close to unauthorized human settlements.

Sediment sampling was done as described by EPA (United States Environmental protection Agency [USEPA], 
2001) using a hand corer ( $30 \mathrm{~cm}$ height, $6 \mathrm{~cm}$ internal diameter). The corer was gently pushed in the mangrove sediments, closed at its upper end with a lid and smoothly removed by twisting and pulling. The sediments were then pushed out of the corer tube using a piston and sectioned into three segments corresponding to depth intervals of 0-3, 3-6 and 6-9 cm. All sediment samples were packed in prior labeled and zipped polyethylene bags, stored in iceboxes and later frozen to $-20{ }^{\circ} \mathrm{C}$. Sediment samples were then air-transported (frozen) to the laboratory of the Department of Analytical and Environmental Chemistry, Vrije Universiteit Brussel (VUB) in Belgium for dioxins and dioxin-like compounds analyses.

\subsection{Chemical Reagents and Standards}

Acetone (Pesti-S grade, minimum 99.9\%), n-hexane (minimum 96\% assay) and toluene (minimum 99.8\% assay) both dioxins and PCB grade, were purchased from Biosolve (The Netherlands). Ethyl acetate (Pestanal, 99.8\% assay) was purchased from Sigma-Aldrich (Germany). Sulphuric acid (95-97\% w/w, ACS reagent) and Dimethylsulfoxide (DMSO) were obtained from Merck (Germany). Glass fibre filters were purchased from Whatman (UK). Alpha-minimal essential medium ( $\alpha$-MEM), fetal bovine serum (FBS) and trypsin $(0.25 \%)$ were obtained from Gibco, UK. Phosphate buffered saline (PBS) was obtained from Ambion (UK). Luciferase assay substrate and buffer were purchased from Promega (The Netherlands). Anhydrous sodium sulphate was purchased from Boom (The Netherlands). The X-CARB was purchased from Xenobiotic Diagnostics Systems, XDS Inc, USA and the solution of 2,3,7,8-TCDD standard (50 $\mu \mathrm{g} / \mathrm{mL}$, purity $99 \%)$ was purchased from Campro Scientific (The Netherlands).

\subsection{Determination of Particle Size and Total Organic Carbon (TOC)}

The concentration of TOC was determined in all 50 sediment samples with a CHN analyzer (Carlo Erba) on a known amount (about $12 \mathrm{mg}$ ) of sediment sub-sample placed in a silver capsule and pre-treated by acidification with $5 \% \mathrm{HCl}$. The grain size distribution was determined by an external laboratory at 3 stations with low, medium and high organic matter (OM) content in their sediments (stations E1, E2 and E7) to test the relation between both variables. Approximately $10 \mathrm{~g}$ lyophilized and homogenized sediment sample was prepared by removing salts, $\mathrm{OM}$ and carbonates using hydrogen peroxide and hydrochloric acid respectively. A stable suspension was obtained after rinsing and adding $5 \mathrm{ml}$ of a peptizing agent. The coarse fraction (above $75 \mu \mathrm{m}$ ) was separated by wet sieving on a $75 \mu \mathrm{m}$ sieve, then dried at $105^{\circ} \mathrm{C}$, and finally dry sieved. The grain-size distribution of the fine fractions $2-75 \mu \mathrm{m}$ and $<2 \mu \mathrm{m}$ was obtained using the Sedigraph 5100 coupled to a Mastertech 51. The precision for 10 consecutive measurements on aliquots of the same sample was around $1 \%$ for each grain-size fraction.

\subsection{Analysis of Dioxin and Dioxin-Like Compounds in Sediments}

\subsubsection{Sample Preparation}

In total, 50 sediment samples were analyzed for PCDD/Fs and dl-PCBs. Lyophilized sediment $(5 \mathrm{~g})$ was extracted using pressurized liquid extraction in an Accelerated Solvent Extractor, ASE ${ }^{\circledR}$, (Dionex, USA) with a toluene:methanol (4:1 v/v) solvent system (Baston \& Denison, 2011) and $33 \mathrm{~mL}$ extraction cells. The ASE extraction conditions were: $125^{\circ} \mathrm{C}$ oven temperature; $1500 \mathrm{psi}(100 \mathrm{MPa})$ pressure; $10 \mathrm{~min}$ static time; $6 \mathrm{~min}$ oven heating time; $60 \mathrm{~s}$ purge time; $60 \%$ of extraction cell volume as flush volume and 2 static cycles. The extracts were then concentrated in a vacuum centrifuge to near dryness and later re-suspended in n-hexane (5 $\mathrm{mL})$.

\subsubsection{Column Preparations for Clean-Up and Fractionation}

The clean up and fractionation is based on the EPA Method 4435 (United States Environmental protection Agency [USEPA], 2008) from which we use the same piggybacked setup of columns. A sequential setup of columns is used to remove PAHs and break down undesired compounds (acid silica gel) and differentially elute PCDD/Fs and dl-PCBs (X-CARB affinity chromatography column). An additional, third, column was added for sulphur removal. Column preparation is described below and all columns are prepared daily.

An activated copper column (for elemental sulphur removal) was prepared by filling a Pasteur pipette from bottom to top with glass wool and $1 \mathrm{~cm}$ of activated (with a $20 \%$ hydrochloric acid solution) copper. The activated copper column was first rinsed with de-ionized water (Milli-Q): $3 \times 1 \mathrm{~mL}$ and then with acetone, toluene and n-hexane (each $3 \times 1 \mathrm{~mL}$ ) in that order. The activated copper columns were stored submerged in n-hexane to avoid oxidation.

An acidified silica column was prepared by filling a $10-\mathrm{mL}$ disposable column (ID $0.8 \mathrm{~mm}$ ), from bottom to top, with glass wool, sodium sulphate $\left(0.5 \mathrm{~cm}^{3}\right)$, sulphuric acid-silica gel $\left(33 \% \mathrm{H}_{2} \mathrm{SO}_{4}\right.$ on silica gel w/w; $\left.4.3 \mathrm{~cm}^{3}\right)$ and sodium sulphate $\left(0.5 \mathrm{~cm}^{3}\right)$. The acid silica column was then rinsed with $\mathrm{n}$-hexane $(3 \times 10 \mathrm{~mL})$. 
Similarly, an X-CARB column was prepared by using an open ended tube (ID $0.8 \mathrm{~mm}$ ), but this was filled (bottom to top) with glass wool, sodium sulphate $\left(0.5 \mathrm{~cm}^{3}\right), 1 \%$ X-CARB $\left(1 \mathrm{~cm}^{3}\right.$ packed), sodium sulphate $(0.5$ $\left.\mathrm{cm}^{3}\right)$ and glass wool. The column was inverted and rinsed sequentially with acetone $(5 \mathrm{ml})$, toluene $(20 \mathrm{ml})$ and n-hexane $(10 \mathrm{ml})$.

The acid silica gel column is placed on top, the copper column in the middle and the X-CARB column at the bottom end prior to sample loading. The individual columns are connected to each other and rinsed with n-hexane ensuring that the columns do not run dry.

\subsubsection{PCDD/Fs and Dl-PCBs Clean up and Fractionation}

The sediment extract in $n$-hexane was first sonicated for 5 minutes followed by vigorous vortexing. An aliquot (2 $\mathrm{mL}$ from the original $5 \mathrm{~mL}$ ) was quantitatively loaded on the acid silica gel column, followed by elution of the column with n-hexane (total $21 \mathrm{~mL}$ ). The acid silica gel and activated copper columns were removed once the solvent had passed through. The remaining X-CARB column was further rinsed with extra n-hexane $(5 \mathrm{~mL})$, followed by elution with a mixture of 8:1:1 of n-hexane:toluene:ethylacetate $(3 \times 5 \mathrm{~mL})$ to collect the fraction containing coplanar PCBs (i.e. PCB fraction). The fraction containing the PCDD/Fs (dioxin fraction) was afterwards eluted (back-flushed) with toluene $(3 \times 5 \mathrm{~mL})$ after inverting the X-CARB column. The PCB and dioxin fractions were later concentrated to dryness in a vacuum centrifuge and re-suspended in n-hexane $(4 \mathrm{~mL})$ for CALUX analysis.

\subsubsection{CALUX Analysis}

CALUX analysis was performed as described elsewhere (Van Langenhove et al., 2011). Briefly, mouse hepatoma cells (H1L7.5c1 cell line) were cultured in $\alpha$-MEM with $10 \% \mathrm{FBS}$ at $37{ }^{\circ} \mathrm{C}, 80 \%$ relative humidity and $5 \% \mathrm{CO}_{2}$. The cells were seeded (at an approximate density of $7.5 \times 10^{5}$ cells $/ \mathrm{mL}$ in a clear bottom 96 -well plate (Greiner Bio-One, Germany) and incubated for 24 hrs to reach a monolayer of cells.

TCDD standard solutions (from $125 \mathrm{nM}$ down to $30 \mathrm{pM}$ ) were made in DMSO and $4 \mu \mathrm{L}$ of this solution was transferred to $2 \mathrm{~mL}$ of n-hexane. Samples were serially diluted in n-hexane and $4 \mu \mathrm{L}$ of DMSO was added to each vial as a carrier solvent. For both the TCDD and sample solutions, the remaining n-hexane was evaporated using a vacuum centrifuge, leaving behind either $4 \mu \mathrm{L}$ DMSO with TCDD standard or $4 \mu \mathrm{L}$ DMSO containing either PCDD/Fs or dl-PCBs from the sample extract.

Prior to dosing, these standards and sample dilutions were diluted 100 times with cell culture media $(4 \mu \mathrm{L}$ standard solution or sample in $396 \mu \mathrm{L} \alpha$-MEM with $10 \%$ FBS). Final solutions were vortexed vigorously and dosed in triplicate $(3 \times 100 \mu \mathrm{L}$ per well).

After 24 hrs of incubation, cells were rinsed and visually inspected for abnormalities. Then, cells were lysed and shaken for $5 \mathrm{~min}$. Luciferin treatment was performed in the Glomax 96-well microplate luminometer (Promega, USA), where the light output in relative light units (RLUs) was measured. Sample responses were expressed as percentage maximum induction to $2,3,7,8-\mathrm{TCDD}\left(\% \mathrm{TCDD}_{\max }\right)$.

\subsection{Statistical Analysis of Data}

TCDD standards were used to generate the calibration curve. A four-variable Hill equation fitting the calibration curve (Elskens et al., 2011) was used to produce a sigmoid curve of the standard solutions. The calibration equation was then used to convert the measured RLU values of the samples into a biological equivalency (CALUX-BEQ) value (Goeyens et al., 2010) by comparing the sample response curve with the sigmoid dose-response curve (Elskens et al., 2011). Further data treatment was done using slope ratio and Box-Cox transformation methods by linearization of the non-linear Hill regression equation as described previously (Elskens et al., 2011). Effective concentrations at $50 \% \mathrm{TCDD}_{\max }\left(\mathrm{EC}_{50}\right)$ of standard and samples were used to determine the potency or bio analytical equivalency (BEQ) of the samples. Statistical analysis was performed using Microsoft Spreadsheet for Windows 2007 and graphical representations were performed using Spreadsheet and Sigmaplot programs (SigmaPlot 10.0). Pearson Correlation and Principal component analysis (PCA) were performed using Predictive Analytic Software (PASW, version 16.0 for Windows) with the PCDD/F and dl-PCB values and the geochemical properties (\% total nitrogen (TN), \% total carbon (TC) and \%TOC) as variables (total 5), and using the mean concentrations of both seasons.

\subsection{Quality Control $(Q C)$ and Quality Assurance ( $Q A)$}

For each batch of samples, a blank sample was introduced through the complete treatment procedure (procedural blank) to monitor the activity contributed by solvents and column matrices used in the sample treatment. Moreover, DMSO and media blanks were added during dosing to detect contamination and to determine the 
experimental background level. All blank samples were measured in triplicate and were treated in a similar way as real samples. The results with $\mathrm{p}<0.05$ (Student T-test) were considered statistically significant.

The limit of detection (LOD) was calculated according to the IUPAC definition. The blank value was taken as the average background of the model fit represented in \%RLU relative to the maximum TCDD-induced RLUs (Elskens et al., 2011).

QC experiments were conducted on each 96-well plate, using an in-house QC solution $(0.250 \mathrm{pg} \mathrm{TCDD} / \mu \mathrm{L})$, to assess precision of the CALUX method and detect bias. Procedural blank fractions were also spiked with the same QC solution prior to dosing to detect agonists and/or potential synergetic or antagonistic effects.

\section{Results and Discussion}

\subsection{Grain Size Distribution}

Sandy particles dominated the mangrove sediments in the study area, with sand $(\mathrm{x}>75 \mu \mathrm{m})$ contributing for more than $60 \%$ of the weight. The correlation between TOC and the fine grain size fraction $(\%<2 \mu \mathrm{m})$ was good $\left(r^{2}=0.92\right)$. This was still the case $\left(r^{2}=0.82\right)$ between TOC and the mud + silt fraction $(\%<75 \mu \mathrm{m})$. It is well-known that muddy sediments having a high TOC content but also a high amount of fine grain size fraction $(<2 \mu \mathrm{m})$, accumulate by far higher amounts of pollutants than sandy sediments (Baeyens et al., 1991). This means that TOC values can eventually be used to normalize the pollutant concentrations in the sediment versus the mud fraction $(\%<2 \mu \mathrm{m})$.

In the Mtoni estuary, the high sand proportion implies that the capacity of the mangrove sediments to adsorb the dioxins and dl-PCBs is medium to low. On the other hand, a high sand fraction favors abiotic processes such as enhanced diffusion of oxygen in the sediment making pollutants more bioavailable due to faster oxidation of organic matter and simultaneous release of associated persistent organic micro-pollutants such as dioxins (Davies \& Tawari, 2010; Holmer, 2003).

\subsection{The CALUX H1L7.5c1 Bioassay}

The CALUX bioassay integrates the responses of every AhR ligand available in the analyzed sample and because of this; it provides only an indication of the possible overall toxicity (Van Langenhove et al., 2011). The results presented in this study show the importance of full-dose curves for environmental samples because the additivity principle is not uphold, despite (1) the use of a sulphuric acid silica gel column in the sample clean up step aimed at eliminating interferences caused by poly-aromatic hydrocarbons (PAHs) and (2) separation of $\mathrm{PCDD} / \mathrm{Fs}$ and dl-PCBs avoiding known antagonistic effects between these two compound groups (Van Langenhove et al., 2011).
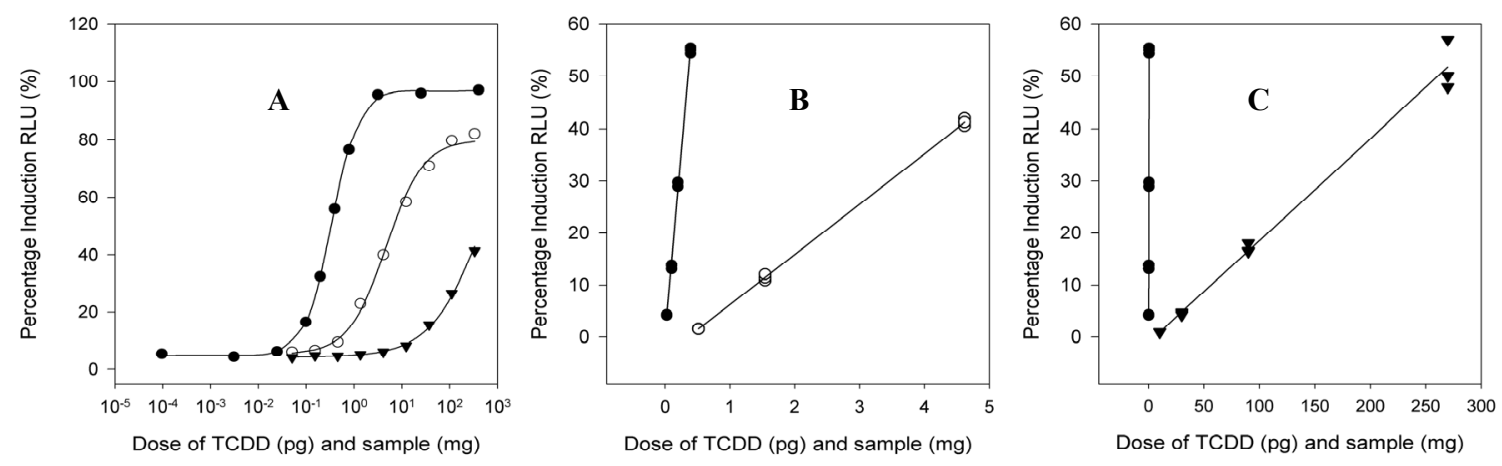

Figure 2. (A) Typical TCDD-standard curve $(\bullet)$, sample with full dose response $(\circ)$ and sample not attaining an

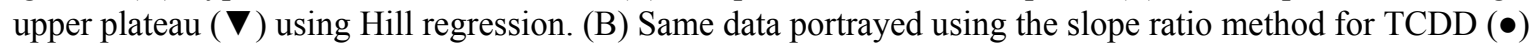
and full dose sample (O). (C) Slope ratio for TCDD $(\bullet)$ and sample without upper plateau $(\boldsymbol{\nabla})$

Luciferase induction was reproducible with coefficients of variation (CV) less than $15 \%$ for a given standard or sample extract measured in triplicate. Mean values of luciferase response measured in three replicate wells were used to generate the dose-response curves. The dose-response curve of TCDD standards was sigmoidal in appearance as shown in Figure 2. 


\subsection{Quality Control}

Blank samples $(n=6)$ spiked with the in-house QC solution $(0.250 \mathrm{pg}$ TCDD $/ \mu \mathrm{L})$ ranged in recoveries from 85 to $120 \%$ for the PCB fraction and from 91 to $115 \%$ for the PCDD fraction, well in accordance with an acceptable relative standard deviation of 20\% (80-120\% recovery of the TCDD spike). DMSO controls showed no marked difference in response to fitted background values $(p=0.45$ for a two-tailed Student T-test). Media controls were generally lower in response, but borderline not statistically significantly different $(p=0.06$ for a two-tailed Student T-test).

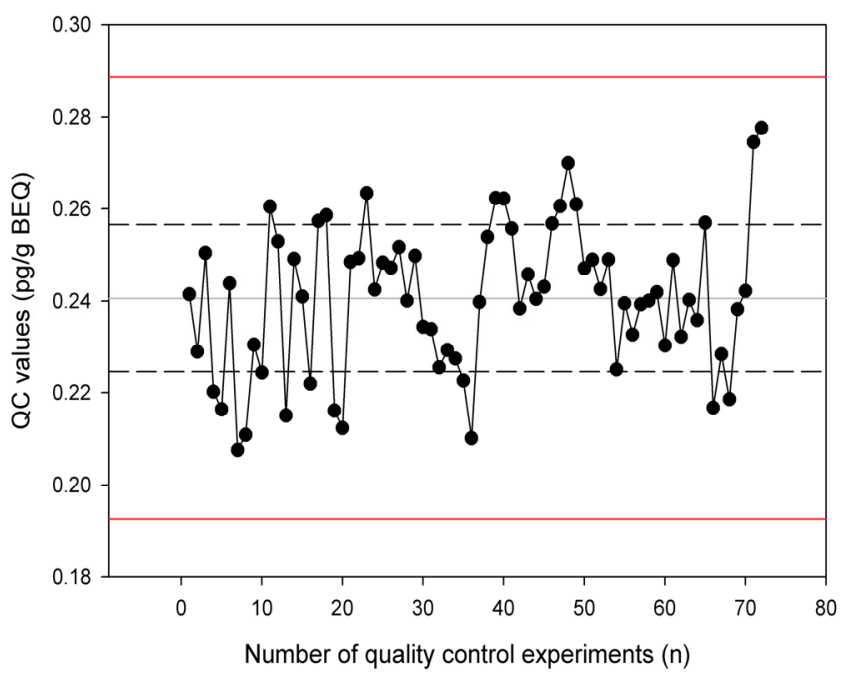

Figure 3. Scatter chart of QC analyses during the study. The dotted lines above and below the mean (0.24) equal the mean $\pm 1 \mathrm{SD}$ values. The 2 additional lines above and below the dotted lines equal the mean $\pm 3 \mathrm{SD}$ values

A total of $72 \mathrm{QC}$ experiments were performed in this study. When these experiments are plotted on a control chart (Figure 3), a mean of $0.24 \pm 0.02 \mathrm{pg} / \mathrm{g}$ indicated that the analysis procedures were reliable with a coefficient of variation (CV) at $7.2 \%$. The LOD based on the averaged fitted background value and on the DMSO blank was $0.05 \mathrm{pg}$ TCDD/well. Recalculating with the starting volume used in the serial dilution, an LOD of about $0.22 \mathrm{pg}$ TCDD/g sediment is found.

\subsection{Bio Analytical Equivalents (BEQs) in Mtoni Sediment Samples}

CALUX-BEQ values of PCDD/Fs in Mtoni estuary sediments were assessed using three methods: the Hill regression equation, Box-Cox transformation (both providing an $\mathrm{EC}_{50}$ in $\mathrm{pg} / \mathrm{g} \mathrm{BEQ}$ ) as well as the slope ratio method (providing a single BEQ value). A detailed description of the methods can be obtained elsewhere (Elskens et al., 2011). The relationships between these methods indicate that they correlate well $\left(\mathrm{r}^{2}>0.8\right.$, Figure 4), implying that either of these methods will provide reliable results in this study. Model precision for BEQ determination based on CVs ranged from 6.7-17.4\% (Hill model), 5.2-14.3\% (Box-Cox transformation) and $5.5-15.5 \%$ (Slope ratio method). 

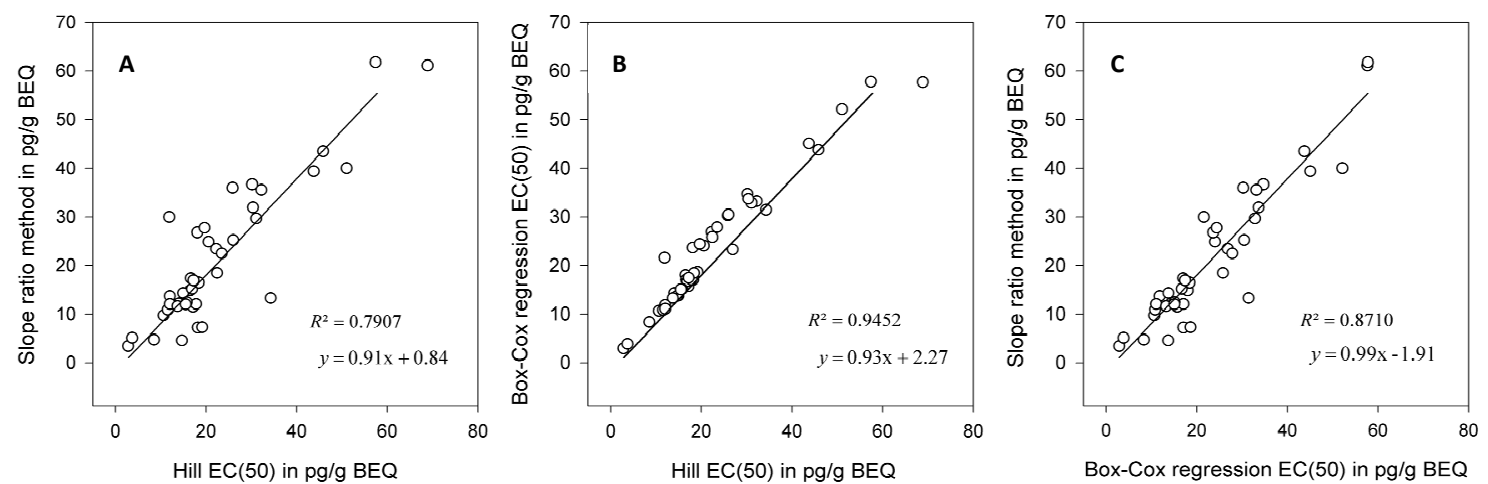

Figure 4. Relationship between PCDD/Fs concentrations $\left(\mathrm{EC}_{50}\right)$ in Mtoni estuary sediment samples; (A) estimated by Hill equation and slope ratio method, (B) Hill regression and Box-Cox transformation and (C) Box-Cox transformation and Slope ratio

Since the Hill equation is the most used method, and for simplicity of comparison, Hill regression BEQs will be continuously employed in this study and are presented in Table 1. To account for non-parallelism that usually exists between dose-response curves of the reference standards and the sample, the BEQ PCDD/F values in a sample were determined based on the $\mathrm{EC}_{20}, \mathrm{EC}_{50}$ and $\mathrm{EC}_{80}$ of the maximum TCDD result (TCDD $\mathrm{TCx}_{\max }$ ).

Dl-PCBs responses are lower than those of PCDD/Fs owing to their lower toxicity equivalent factors (TEFs). Their potency was therefore determined using inverse prediction, assuming a sample behaves like a diluted TCDD standard solution (Elskens et al., 2011).

In order to eliminate concentration differences emanating from variations in the sand fraction of the sediments, pollutant concentrations in the Mtoni estuary sediments were normalised to TOC. Despite the normalisation, PCDD/F and dioxin-like PCB profiles showed no obvious vertical trends. The rather steady depth profiles indicate that the estuarine sediments are fairly well-mixed making the profiles more or less uniform. It is possible that the hydrodynamics of the estuary (tidal amplitude of up to $5 \mathrm{~m}$ at the mouth) provide frequent sediment mixing, smoothing out possible vertical concentration gradients. Perhaps, a depth of 9-cm is not sufficient enough to observe any difference and therefore it may be interesting in the future to study pollutant profiles in deeper sediment layers. 
Table 1. Mtoni estuary sediment properties and the CALUX-BEQ values for PCDD/Fs and PCBs

\begin{tabular}{|c|c|c|c|c|c|c|}
\hline \multirow[b]{2}{*}{ Code and Location } & \multirow[b]{2}{*}{$\begin{array}{c}\text { Section } \\
\text { depth }(\mathrm{cm})\end{array}$} & \multirow[b]{2}{*}{ Season } & \multirow[b]{2}{*}{$\begin{array}{l}\text { TOC } \\
(\%)\end{array}$} & \multicolumn{3}{|c|}{ CALUX-BEQ (pg TCDD/g sediment) } \\
\hline & & & & $\begin{array}{c}\text { PCDD/Fs } \\
\text { BEQ }_{50}\end{array}$ & $\begin{array}{c}\text { PCDD/Fs } \\
\text { BEQ }_{20}-\mathrm{BEQ}_{80} \text { range }\end{array}$ & $\begin{array}{c}\text { Dioxin-like } \\
\text { PCBs* }\end{array}$ \\
\hline \multirow{6}{*}{$\begin{array}{l}\text { E1: } \\
\text { S } 06^{\circ} 52.443 \\
\text { E } 039^{\circ} 17.014\end{array}$} & $0-3 \mathrm{~cm}$ & wet & 0.62 & 31.07 & $44.6-21.6$ & 0.35 \\
\hline & & dry & 1.86 & 51.02 & $63.3-41.1$ & 0.47 \\
\hline & $3-6 \mathrm{~cm}$ & wet & 0.63 & 34.28 & $45.4-25.9$ & 0.33 \\
\hline & & dry & 1.77 & 30.37 & $53.0-17.4$ & 1.03 \\
\hline & $6-9 \mathrm{~cm}$ & wet & 0.50 & 22.45 & $28.0-18.0$ & 0.34 \\
\hline & & dry & 2.23 & 17.13 & $24.0-12.2$ & 0.26 \\
\hline \multirow{6}{*}{$\begin{array}{l}\text { E2: } \\
\text { S } 06^{\circ} 52.357 \\
\text { E } 039^{\circ} 17.099\end{array}$} & $0-3 \mathrm{~cm}$ & wet & 1.02 & 18.20 & $22.3-14.9$ & 0.38 \\
\hline & & dry & 1.46 & 45.84 & $55.7-37.7$ & 0.63 \\
\hline & $3-6 \mathrm{~cm}$ & wet & 1.02 & 23.50 & $31.4-17.6$ & 0.34 \\
\hline & & dry & 0.56 & 11.58 & $15.4-8.7$ & 0.26 \\
\hline & $6-9 \mathrm{~cm}$ & wet & 0.56 & 14.93 & $21.5-10.4$ & 0.33 \\
\hline & & dry & 0.24 & 14.02 & $20.0-10.0$ & 0.24 \\
\hline \multirow{6}{*}{$\begin{array}{l}\text { E3: } \\
\text { S06 } 52.058 \\
\text { E } 39^{\circ} 17.355\end{array}$} & $0-3 \mathrm{~cm}$ & wet & 2.55 & 68.87 & $85.7-55.4$ & 0.47 \\
\hline & & dry & 1.35 & 57.42 & $72.6-45.4$ & 0.41 \\
\hline & $3-6 \mathrm{~cm}$ & wet & 3.57 & 30.18 & $38.2-23.9$ & 0.15 \\
\hline & & dry & 0.68 & 22.25 & $43.6-11.4$ & 0.40 \\
\hline & $6-9 \mathrm{~cm}$ & wet & 3.83 & 20.54 & $32.2-13.1$ & 0.14 \\
\hline & & dry & 0.66 & 16.48 & $19.4-14.0$ & 0.11 \\
\hline \multirow{6}{*}{$\begin{array}{l}\text { E4: } \\
\text { S 0652.090 } \\
\text { E } 039^{\circ} 17.501\end{array}$} & $0-3 \mathrm{~cm}$ & wet & 1.04 & 32.22 & $42.7-24.3$ & 0.48 \\
\hline & & dry & 0.98 & 26.93 & $81.2-8.90$ & 0.27 \\
\hline & $3-6 \mathrm{~cm}$ & wet & 1.15 & 18.10 & $31.5--10.4$ & 0.28 \\
\hline & & dry & 1.71 & 43.73 & $49.9-38.4$ & 0.55 \\
\hline & $6-9 \mathrm{~cm}$ & wet & 1.23 & 16.66 & $20.0-13.9$ & 0.39 \\
\hline & & dry & 0.96 & 25.86 & $42.8-15.6$ & 0.10 \\
\hline \multirow{6}{*}{$\begin{array}{l}\text { E5: } \\
\text { S 0652.164 } \\
\text { E 039 } 17.658\end{array}$} & $0-3 \mathrm{~cm}$ & wet & 2.38 & 10.63 & $12.9-8.75$ & 0.25 \\
\hline & & dry & 0.70 & 11.88 & $15.9-8.89$ & 0.55 \\
\hline & $3-6 \mathrm{~cm}$ & wet & 0.90 & 2.82 & $3.73-2.31$ & 0.18 \\
\hline & & dry & 0.80 & 19.66 & $35.3-11.0$ & 0.47 \\
\hline & $6-9 \mathrm{~cm}$ & wet & 1.40 & 3.70 & $5.29-2.59$ & 0.23 \\
\hline & & dry & 0.46 & 12.02 & $16.0-9.00$ & 0.36 \\
\hline \multirow{6}{*}{$\begin{array}{l}\text { E6: } \\
\text { S } 06^{\circ} 52.882 \\
\text { E } 039^{\circ} 18.391\end{array}$} & $0-3 \mathrm{~cm}$ & wet & 3.12 & 26.00 & $36.9-18.3$ & 0.28 \\
\hline & & dry & 3.57 & 18.38 & $24.1-14.0$ & 0.39 \\
\hline & $3-6 \mathrm{~cm}$ & wet & 4.42 & 13.72 & $19.2-9.81$ & 0.19 \\
\hline & & dry & 3.01 & 17.22 & $25.4-11.7$ & 0.26 \\
\hline & $6-9 \mathrm{~cm}$ & wet & 2.54 & 15.73 & $22.9-10.8$ & 0.18 \\
\hline & & dry & 4.30 & 15.51 & $22.7-10.6$ & 0.24 \\
\hline \multirow{6}{*}{$\begin{array}{l}\text { E7: } \\
\text { S } 06^{\circ} 52.952 \\
\text { E } 039^{\circ} 18.454\end{array}$} & $0-3 \mathrm{~cm}$ & wet & 7.50 & 16.91 & $24.5-11.7$ & 0.54 \\
\hline & & dry & 1.35 & 14.70 & $19.4-11.7$ & 0.19 \\
\hline & $3-6 \mathrm{~cm}$ & wet & 2.41 & 17.80 & $25.6-12.4$ & 0.44 \\
\hline & & dry & 1.72 & 19.17 & $25.4-14.4$ & 0.23 \\
\hline & $6-9 \mathrm{~cm}$ & wet & 7.07 & 12.04 & $17.1-8.45$ & 0.60 \\
\hline & & dry & 1.66 & 8.52 & $12.4-5.85$ & 0.24 \\
\hline
\end{tabular}

*Results were determined by the inverse prediction method.

The PCDD/F results from the CALUX screening for the Mtoni estuary sediment extracts are shown in Figure 5A. The PCDD/F concentrations in figure $5 \mathrm{~A}$ were based on the Hill $\mathrm{BEQ}_{50}$ and ranged from $5.7 \pm 1.4$ to $39.9 \pm 5.8$ $\mathrm{pg} \mathrm{BEQ} / \mathrm{g}$ sediment in wet season and were between $14.1 \pm 2.0$ and $32.8 \pm 4.7 \mathrm{pg} \mathrm{BEQ} / \mathrm{g}$ sediment in dry season. Higher levels of PCDD/Fs in both seasons were found in the Kizinga River and in confluence stations close to it. Wet season samples contained less PCDD/Fs than dry season samples in the Kizinga River, however at the Mzinga site it was the opposite. Higher PCDD/F levels at confluence station E3 in both seasons could be due to a 
local emission source in proximity to the Kizinga River. This is confirmed by the subsequent higher levels at the nearby station E4 in both seasons and lower levels at E5, a station closer to the Mzinga River. No significant difference $(\mathrm{t}=0.55$ two tailed; $\mathrm{p}=0.59)$ in PCDD/F levels was observed between the two seasons $(\mathrm{n}=42)$.

Response levels of dl-PCBs (Figure 5B) ranged from $0.21 \pm 0.03$ to $0.53 \pm 0.03 \mathrm{pg} \mathrm{BEQ} / \mathrm{g}$ sediment in wet season and from $0.22 \pm 0.03$ to $0.59 \pm 0.04 \mathrm{pg} \mathrm{BEQ} / \mathrm{g}$ sediment in dry season. These BEQ values are much lower (about 2 orders of magnitude) than those of the PCDD/Fs. At the 2 Kizinga stations, confluence station E5 and Mzinga station E6, lower PCBs values were observed in wet compared to dry season, while the opposite was true for confluence stations E3 and E4 as well as Mzinga station E7. High dioxin-like PCB levels were generally correlated to high PCDD/Fs values. The PCB levels detected in the estuary showed no significant variations $(\mathrm{t}=$ 0.27 two tailed; $p=0.79)$ between the seasons $(n=42)$.
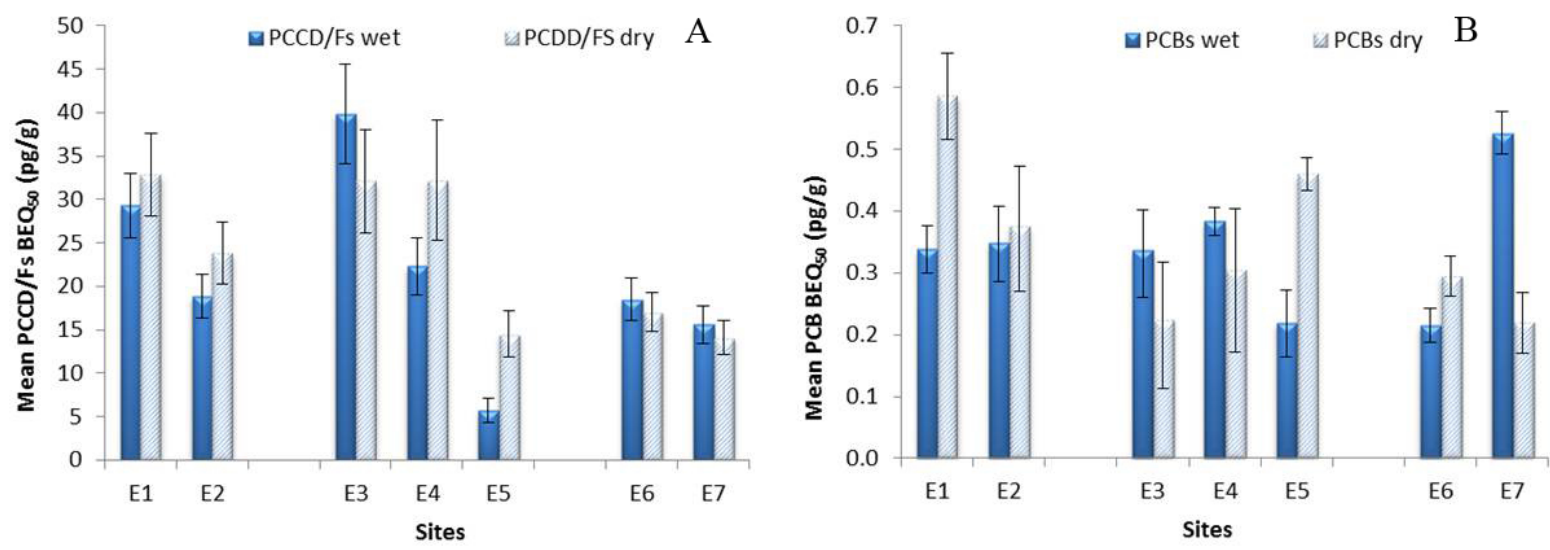

Figure 5. BEQ (with uncertainty error bars) for PCDD/Fs (A) and PCBs (B) of the Mtoni sediments presented as averaged values of the three depth layers in dry and wet seasons

The Kizinga River drains the peri-urban environments of Temeke, Mbagala, Ukonga, Charambe, Kijichi, Vituka, Keko, Kitunda, Mtoni, and Kurasini which are highly populated and have many small-scale to medium-scale industries. On the other hand, the Mzinga stream drains the rural environments of Mji Mwema, Vijibweni and Tuangoma that are less populated and have very few industries. As a result of various socio-economic activities, polymeric materials (household scraps, plastics, vehicle tires and electronic wastes) are abundantly present in most domestic and industrial wastes. Due to lack of appropriate infrastructures, most of these wastes are collected in open dumping sites and then burnt. Polymeric materials in wastes, when subjected to open burning, may lead to formation of PCDD/Fs and dl-PCBs (Estrellan \& Iino, 2010). In addition, 2 other sources of PCDD/Fs and dl-PCBs have to be considered in the study area: (1) charcoal and/ or wood burning is the main source of energy for domestic purposes; (2) privately owned second hand commuter buses that need frequent services are the main means of transport for most residents. It was observed (Mkoma, 2008) that biomass burning (wood and charcoal burning) and traffic-related emissions (leaded gasoline exhausts and spills, tire wear) are the major sources of particulate matter in the Dar es Salaam atmosphere. The detected PCDD/Fs and dl-PCBs levels in the estuary can thus reasonably be associated with the open burning of polymeric waste, domestic wood/charcoal burning and with traffic-related emissions.

The presence of sources in the vicinity of the sampling stations must also be taken into account to explain the detected levels of PCDD/Fs and dl-PCBs. For example, upstream station E1 in the Kizinga River is downstream to an untreated wastewater discharge point of a textile factory. Higher levels of both PCDD/F and dl-PCBs in Kizinga stations compared to Mzinga stations may reflect the combined effects of the denser population and the more industrial activities in the Kizinga River basin because both are directly related to the various sources of $\mathrm{PCDD} / \mathrm{Fs}$ and dl-PCBs mentioned above.

A third sampling campaign was organised to verify the higher PCDD/F and dl-PCB levels in the Kizinga River and to assess the change of the dioxin levels downstream the previous sampling stations in the estuary (E1 to E5). The most upstream sampling station in the Kizinga River (F1) which is $200 \mathrm{~m}$ upstream of a sewage factory pipe and near unauthorised human settlements, is very rich in organic matter (Table 2). Station F1 shows a high 
$\mathrm{PCDD} / \mathrm{F}$ level of $400 \mathrm{pg}-\mathrm{BEQ} / \mathrm{g}$ and a dl-PCB level of $0.91 \mathrm{pg}-\mathrm{BEQ} / \mathrm{g}$. The second upstream Kizinga River sample (F2) is also high but not exceptional with $21 \mathrm{pg}-\mathrm{BEQ} / \mathrm{g}$ PCDD/Fs and $0.63 \mathrm{pg}-\mathrm{BEQ} / \mathrm{g}$ dl-PCBs. The levels in the upstream Mzinga River samples are close to those of the Kizinga River sample F2 (Table 2). A negative concentration gradient of PCDD/Fs and dl-PCBs in sediments is observed in the downstream direction. The levels at the mouth of the Mtoni estuary are very low: 1 to $2 \mathrm{pg}-\mathrm{BEQ} / \mathrm{g}$ for PCDD/Fs and below LOD for dl-PCBs. These additional results confirm the previous conclusions that the impact of dioxins on the Kizinga River basin is higher than on that of the Mzinga River and that a dilution effect is clearly noticeable in the downstream direction.

Table 2. CALUX-BEQ values for PCDD/Fs and dl-PCBs in additional end-member samples

\begin{tabular}{|c|c|c|c|c|c|}
\hline & \multirow[b]{2}{*}{ Code and Location } & \multirow[b]{2}{*}{$\begin{array}{l}\text { TOC } \\
(\%)\end{array}$} & \multicolumn{3}{|c|}{ CALUX-BEQ (pg TCDD/g sediment) } \\
\hline & & & $\begin{array}{c}\mathrm{PCDD} / \mathrm{Fs} \\
\mathrm{BEQ}_{50} \\
\end{array}$ & $\begin{array}{c}\mathrm{PCDD} / \mathrm{Fs} \\
\text { BEQ }_{20}-\mathrm{BEQ}_{80} \text { range }\end{array}$ & $\begin{array}{c}\text { Dioxin-like } \\
\text { PCBs* }\end{array}$ \\
\hline $\mathrm{F} 1$ & $\begin{array}{l}\text { S } 06^{\circ} 53^{\prime} 01.29^{\prime \prime} \\
\text { E } 039^{\circ} 15^{\prime} 48.33^{\prime \prime}\end{array}$ & 8.58 & 397 & $652-242$ & 0.91 \\
\hline $\mathrm{F} 2$ & $\begin{array}{l}\text { S 0652'58.07’' } \\
\text { E 039॰16’06.81', }\end{array}$ & 2.08 & 20.7 & $26.7-16.0$ & 0.68 \\
\hline F3 & 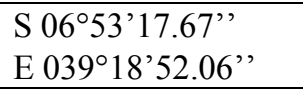 & 1.05 & 17.2 & $21.0-14.2$ & 0.60 \\
\hline F4 & $\begin{array}{l}\text { S 0653'13.60"' } \\
\text { E } 039^{\circ} 18^{\prime} 52.69^{\prime \prime}\end{array}$ & 0.56 & 12.5 & $15.8-9.86$ & 0.74 \\
\hline F5 & 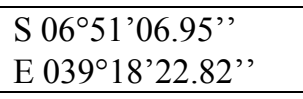 & 0.85 & 6.71 & $7.70-5.85$ & 0.25 \\
\hline F6 & $\begin{array}{l}\text { S } 06^{\circ} 50^{\prime} 57.46^{\prime \prime} \\
\text { E } 39^{\circ} 18^{\prime} 19.16^{\prime \prime}\end{array}$ & 0.72 & 6.82 & $7.47-6.23$ & 0.23 \\
\hline F7 & $\begin{array}{l}\text { S 06² } 49^{\prime} 03.71^{\prime \prime} \\
\text { E } 39^{\circ} 18^{\prime} 24.11^{\prime \prime}\end{array}$ & 0.28 & 1.66 & $2.43-1.14$ & $<\mathrm{LOD}$ \\
\hline F8 & $\begin{array}{l}\text { S } 06^{\circ} 48^{\prime} 57.62^{\prime \prime} \\
\text { E } 39^{\circ} 18^{\prime} 34.60^{\prime \prime}\end{array}$ & 0.99 & 1.03 & $1.74-0.61$ & $<\mathrm{LOD}$ \\
\hline
\end{tabular}

*Results were determined by the inverse prediction method.

\subsection{Correlation Between Pollutants and Sediment Geochemical Characteristics}

Calculations of the Pearson correlation coefficients were performed on pollutant levels as well as sediment geochemical characteristics of all samples $(n=42)$ in the mixing zone in both seasons (Table 3$)$. A significant correlation was observed between PCDD/Fs and dioxin-like PCB levels $\left(r^{2}=0.40, p<0.05\right)$, however, no significant correlations ( $p>0.05$ ) were found with \% TOC although it is well-known that lipophilic compounds such as PCDD/Fs and dl-PCBs tend to preferably associate with organic fractions (Koh et al., 2004, 2006; Pieters, 2007).

Table 3. Correlation coefficients between pollutants and various geochemical parameters

\begin{tabular}{lccccc}
\hline & PCDD/Fs & PCBs & \%TOC & \%TN & \%TC \\
\hline PCDDs & 1.000 & & & & \\
PCBs & $\mathbf{0 . 3 9 5 *}$ & 1.000 & & & \\
\%TOC & 0.070 & 0.208 & 1.000 & & \\
\%TN & -0.049 & 0.120 & $\mathbf{0 . 9 1 3 *}$ & 1.000 & \\
\%TC & -0.065 & 0.172 & $\mathbf{0 . 8 2 3 *}$ & $\mathbf{0 . 8 9 3 *}$ & 1.000 \\
\hline
\end{tabular}

* Significant at $\alpha=0.05$. 
The weak correlation between the pollutants and \%TOC is contrary to the theoretical expectation explained elsewhere (Hilscherova et al., 2003), but the sources of TOC and PCDD/Fs or dl-PCBs are quite different in the Mtoni study area. TOC in the estuary and rivers is mainly originating from 2 sources: (1) mangrove degradation compounds (Marchand, Lallier-Vergès, \& Baltzer, 2003) and (2) untreated domestic sewage water (Mihale, Kishimba, Baeyens, \& Brion, 2013), while PCDD/Fs and dl-PCBs originate from open burning processes (Lee, Coleman, J. Jones, K. Jones, \& Lohmann, 2005) and traffic related emissions (Coleman, Lee, Alcock, \& Jones, 1997). A mixing of the PCDD/Fs or dl-PCBs with the organic matter in the estuary can occur in all kind of ratios. It is thus not surprising that there exists no correlation between both variables. Good and significant correlations $(\mathrm{p}<0.05)$ were observed between $\%$ TOC, $\% \mathrm{TC}$ and $\% \mathrm{TN}$.

\subsection{Pollutant Source Analysis by PCA}

Multivariate analysis can be used to identify similarities and differences between pollutants in samples as a means to detect possible sources. As we could expect, the PCA results indicated that the variables can be represented by two principal components that account for $83.7 \%$ of the total variance in the original data sets. Based on the loading distribution of the variables, \% TC, \% TN and \% TOC constituted one related group (PC1), while the pollutants PCDD/Fs and dl-PCBs formed the other group (PC2).

\subsection{Comparison with Other Studies and with Sediment Quality Guidelines}

Little information is available in literature regarding CALUX analysis of PCDD/Fs and dl-PCBs in marine, estuarine and river sediments. No such research has been conducted in Tanzania as a whole. Research on dioxin-like compounds in such sediments in the world used chemo-analysis or GC-HRMS, because this method is considered as the golden standard (Baeyens et al., 2004). Furthermore, most research focused on PCDD/Fs while no data on dl-PCBs were available for comparison. Comparison with literature data indicated that the observed PCDD/F levels were covering the ranges observed in the literature (see Table 4). Only at the Belgian coast where lower values were observed (Sanctorum et al., 2007).

An attempt was made to compare the PCDD/F and dioxin-like PCB levels with the sediment quality guidelines. Since Tanzania lacks these guidelines, National Oceanic and Atmospheric Administration (NOAA), USA and Canadian Sediment quality guidelines were applied to assess the toxicity and risk of the dioxin-like pollutants in the Mtoni estuary ecosystem. Mangrove sediments from Mtoni estuary have higher PCDD/F levels than the NOAA apparent effects threshold (AET) of $3.6 \mathrm{pg}-\mathrm{TEQ} / \mathrm{g}$. The levels were also higher than both the threshold effect level (TEL) for Canadian sediment quality guideline $(0.85 \mathrm{pg}-\mathrm{TEQ} / \mathrm{g})$ and the probable effect level (PEL) of $21.5 \mathrm{pg}-\mathrm{TEQ} / \mathrm{g}$. There were no specific guidelines for dl-PCB levels.

Table 4. Comparison of PCDD/F and PCB levels (pg-BEQ/g dw) determined by CALUX bioassay in different marine sedimentary environments

\begin{tabular}{|c|c|c|c|}
\hline Study site & $\mathrm{PCDD} / \mathrm{Fs}^{1}$ & $\mathrm{PCBs}^{2}$ & Reference \\
\hline$\overline{\text { Mtoni estuary, Tanzania }^{3}}$ & $1.0-397$ & $<$ LOD-0.91 & This study \\
\hline UK estuaries & $1.0-88$ & - & (Hurst et al., 2004) \\
\hline Hong Kong mudflats & $3-68$ & - & (Wong, Giesy, Siu, \& Lam, 2005) \\
\hline North coast of Bohai Sea, China & $3.4-28$ & - & (Hong et al., 2012) \\
\hline Masan Bay, Korea & $17-275$ & - & (Yoo, Khim, \& Giesy, 2006) \\
\hline Belgian coast & $0.08-42.4$ & - & (Sanctorum et al., 2007) \\
\hline West coast, South Korea & $3.4-11$ & - & (Hong et al., 2012) \\
\hline
\end{tabular}

${ }^{1}$ Values presented are $\mathrm{BEQ}_{50} ;{ }^{2}$ values are inversely predicted; ${ }^{3}$ Values indicate the range of mean BEQ of both seasons $(n=6)$.

The comparisons have shown that there could currently be a risk regarding PCDD/Fs, while the risk associated with dl-PCBs is much lower. Because the toxicity of these chemicals is assumed additive, increasing levels in line with the increasing anthropogenic activities can be alarming to the local biological community (Kruitwagen, Hecht, Pratap, \& Wendelaar-Bonga, 2005) such as the barred mudskippers and soft bottom mollusks that inhabit the muddy areas. Presence of these pollutants in mangrove sediments may cause impairments, like abnormal growth and malformations. The effects can reach other organisms higher in the trophic level due to their 
bio-accumulation, bio-concentration and persistent properties. The levels of pollutants observed in the frequently exchanged upper $(0-3 \mathrm{~cm})$ layer can have impacts on the distribution and fate of pollutants to mangrove ecosystems and to higher organisms that use mangrove sediment organisms as their food.

\section{Conclusion}

This study is the first of its kind that used in vitro bioassay analysis (CALUX) to determine dioxin and dioxin-like compounds in the environment of East Africa. Sediment samples were collected in the Mtoni estuary and its tributaries, the Kizinga and the Mzinga Rivers, in the vicinity of Dar es Salaam. While it is well known that anthropogenic activities as open burning of plastic scrap, household burning of wood or charcoal and traffic related emissions, which all frequently occur in the Dar es Salaam region, can lead to PCDD/F and dioxin-like PCB production, it was totally unknown if some or all of those sources resulted in the contamination of the nearby aquatic systems. Our CALUX analyses of the sediments in the Mtoni estuary and its 2 tributaries demonstrated that the range of PCDD/F values (1.0 to $400 \mathrm{pg}-\mathrm{BEQ} / \mathrm{g}$-sediment) covers the ranges observed in sediments from Western Europe and Eastern Asia. Neither significant seasonal variations nor vertical gradients in the sediments could be observed. For dl-PCBs we could not find sediment results obtained by CALUX in the literature. Sediments in the Kizinga River, which flows through a denser populated and more industrialised area than the Mzinga River, showed also higher PCDD/F and dioxin-like PCB levels. Finally, the overall BEQ value of dioxins (PCDD/F and dioxin-like PCB levels) observed in sediments of the Dar es Salaam region, indicate possible ecological and human risks that may emanate from these contaminants.

\section{Acknowledgements}

This work was supported by the Belgian Technical Cooperation (BTC) under the Belgian Development Agency through a scholarship offered to M. J. Mihale. The CALUX bioassay H1L7.5c1 cell line was developed with funding from the National Institute of Environmental Health Sciences Superfund Research grant (ES04699) by Prof. Michael S. Denison, UC Davis, who kindfully provided us with the cells. MJM is very grateful to Prof. Michael Kishimba, who passed away during this research, for his unlimited support.

\section{References}

Baeyens, W., Panutrakul, I. S., Elskens, M., Navez, M. L. J., \& Monteny, F. (1991). Geochemical Processes in Muddy and Sandy Tidal Flat Sediments. Geo-Marine Letters, 188-193. http://dx.doi.org/10.1007/BF02431011

Baeyens, Willy, Verstraete, F., \& Goeyens, L. (2004). Elucidation of sources, pathways and fate of dioxins, furans and PCBs requires performant analysis techniques. Talanta, 63(5), 1095-100. http://dx.doi.org/10.1016/j.talanta.2004.06.010

Baston, D. S., \& Denison, M. S. (2011). Considerations for potency equivalent calculations in the Ah receptor-based CALUX bioassay: normalization of superinduction results for improved sample potency estimation. Talanta, 83(5), 1415-21. http://dx.doi.org/10.1016/j.talanta.2010.11.035

Besselink, H. T., Schipper, C., Klamer, H., Leonards, P., Verhaar, H., Felzel, E., ... Brouwer, B. (2004). Intraand interlaboratory calibration of the DR CALUX bioassay for the analysis of dioxins and dioxin-like chemicals in sediments. Environmental Toxicology and Chemistry/SETAC, 23(12), 2781-9. Retrieved from http://www.ncbi.nlm.nih.gov/pubmed/15648750

Birch, G. F., Harrington, C., Symons, R. K., \& Hunt, J. W. (2007). The source and distribution of polychlorinated dibenzo-p-dioxin and polychlorinated dibenzofurans in sediments of Port Jackson, Australia. Marine Pollution Bulletin, 54(3), 295-308. http://dx.doi.org/10.1016/j.marpolbul.2006.10.009

Bruckmeier, B. F. A., Jüttner, I., Schramm, K. W., Winkler, R., Steinberg, C. E. W., \& Kettrup, A. (1997). PCBs and PCDD/Fs in lake sediments of Großer Arbersee, Bavarian Forest, South Germany. Environmental Pollution, 95(1), 19-25. http://dx.doi.org/10.1016/S0269-7491(96)00118-2

Chi, K. H., Chang, M. B., \& Kao, S. J. (2007). Historical trends of PCDD/Fs and dioxin-like PCBs in sediments buried in a reservoir in Northern Taiwan. Chemosphere, 68(9), 1733-40. http://dx.doi.org/10.1016/j.chemosphere.2007.03.043

Coleman, P. J., Lee, R. G. M., Alcock, R. E., \& Jones, K. C. (1997). Observations on PAH, PCB, and PCDD/F Trends in U.K. Urban Air, 1991-1995. Environmental Science \& Technology, 31(7), 2120-2124. http://dx.doi.org/10.1021/es960953q 
Croes, K., Van Langenhove, K., Elskens, M., Desmedt, M., Roekens, E., Kotz, A., ... Baeyens, W. (2011). Analysis of PCDD/Fs and dioxin-like PCBs in atmospheric deposition samples from the Flemish measurement network: Optimization and validation of a new CALUX bioassay method. Chemosphere, 82(5), 718-24. http://dx.doi.org/10.1016/j.chemosphere.2010.10.092

Davies, O. A., \& Tawari, C. C. (2010). Season and tide effects on sediment characteristics of trans-okpoka creek, upper bonny Estuary, Nigeria. Agriculture and Biology Journal of North America, 1(2), 89-96.

De Wolf, H., \& Rashid, R. (2008). Heavy metal accumulation in Littoraria scabra along polluted and pristine mangrove areas of Tanzania. Environmental Pollution, 152(3), 636-43. http://dx.doi.org/10.1016/j.envpol.2007.06.064

Denison, M. S., Pandini, A., Nagy, S. R., Baldwin, E. P., \& Bonati, L. (2002). Ligand binding and activation of the $\mathrm{Ah}$ receptor. Chemico-Biological Interactions, $141(1-2), \quad 3-24$. http://dx.doi.org/10.1016/S0009-2797(02)00063-7

Denison, M. S., Zhao, B., Baston, D. S., Clark, G. C., Murata, H., \& Han, D. (2004). Recombinant cell bioassay systems for the detection and relative quantitation of halogenated dioxins and related chemicals. Talanta, 63(5), 1123-33. http://dx.doi.org/10.1016/j.talanta.2004.05.032

El-Kady, A. A., Abdel-Wahhab, M. A., Henkelmann, B., Belal, M. H., Morsi, M. K. S., Galal, S. M., \& Schramm, K. W. (2007). Polychlorinated biphenyl, polychlorinated dibenzo-p-dioxin and polychlorinated dibenzofuran residues in sediments and fish of the River Nile in the Cairo region. Chemosphere, 68(9), 1660-8. http://dx.doi.org/10.1016/j.chemosphere.2007.03.066

Elskens, M., Baston, D. S., Stumpf, C., Haedrich, J., Keupers, I., Croes, K., ... Goeyens, L. (2011). CALUX measurements: statistical inferences for the dose-response curve. Talanta, 85(4), 1966-73. http://dx.doi.org/10.1016/j.talanta.2011.07.014

Estrellan, C. R., \& Iino, F. (2010). Toxic emissions from open burning. Chemosphere, 80(3), 193-207. http://dx.doi.org/10.1016/j.chemosphere.2010.03.057

Goeyens, L., Hoogenboom, R., Eppe, G., Malagocki, P., Vanderperren, H., Scippo, M. L., ... Haedrich, J. (2010). Discrepancies between Bio-analytical and Chemo-analytical results have a non-negligible message. Organohalogen Compounds, 72, 964-967.

Guzzella, L., Roscioli, C., Viganò, L., Saha, M., Sarkar, S. K., \& Bhattacharya, A. (2005). Evaluation of the concentration of $\mathrm{HCH}, \mathrm{DDT}, \mathrm{HCB}, \mathrm{PCB}$ and PAH in the sediments along the lower stretch of Hugli estuary, West Bengal, northeast India. Environment International, 31(4), 523-34. http://dx.doi.org/10.1016/j.envint.2004.10.014

Hilscherova, K., Kannan, K., Nakata, H., Hanari, N., Yamashita, N., Bradley, P. W., ... Giesy, J. P. (2003). Polychlorinated Dibenzo- $\mathrm{p}$-dioxin and Dibenzofuran Concentration Profiles in Sediments and Flood-Plain Soils of the Tittabawassee River, Michigan. Environmental Science \& Technology, 37(3), 468-474. $\mathrm{http}: / / \mathrm{dx}$. doi.org/10.1021/es020920c

Holmer, M. (2003). Biogeochemistry of Marine Systems. In K. D. Black \& G. B. Shimmield (Eds.), Journal of Marine Systems (Vol. 50, pp. 1-34). Blackwell Publishing Ltd. http://dx.doi.org/10.1016/j.jmarsys.2004.05.004

Hong, S., Khim, J. S., Naile, J. E., Park, J., Kwon, B. O., Wang, T., ... Giesy, J. P. (2012). AhR-mediated potency of sediments and soils in estuarine and coastal areas of the Yellow Sea region: a comparison between Korea and China. Environmental Pollution, 171, 216-25. http://dx.doi.org/10.1016/j.envpol.2012.08.001

Hoogenboom, L., Traag, W., Bovee, T., Goeyens, L., Carbonnelle, S., Vanloco, J., ... Baeyens, W. (2006). The CALUX bioassay: Current status of its application to screening food and feed. TrAC Trends in Analytical Chemistry, 25(4), 410-420. http://dx.doi.org/10.1016/j.trac.2006.02.012

Hurst, M. R., Balaam, J., Chan-Man, Y. L., Thain, J. E., \& Thomas, K. V. (2004). Determination of dioxin and dioxin-like compounds in sediments from UK estuaries using a bio-analytical approach: chemical-activated luciferase expression (CALUX) assay. Marine Pollution Bulletin, 49(7-8), 648-58. http://dx.doi.org/10.1016/j.marpolbul.2004.04.012 
International POPs Elimination Network. (2005). Contamination of chicken eggs near the Vikuge obsolete pesticides stockpile in Tanzania by dioxins, PCBs and hexachlorobenzene Contamination of chicken eggs near the Vikuge obsolete pesticides stockpile in Tanzania by dioxins (pp. 0-22).

Joung, K. E., Chung, Y. H., \& Sheen, Y. Y. (2007). DRE-CALUX bioassay in comparison with HRGC/MS for measurement of toxic equivalence in environmental samples. Science of The Total Environment, 372(2-3), 657-67. http://dx.doi.org/10.1016/j.scitotenv.2006.10.036

Koh, C-H, Khim, J. S., Kannan, K., Villeneuve, D. L., Senthilkumar, K., \& Giesy, J. P. (2004). Polychlorinated dibenzo-p-dioxins (PCDDs), dibenzofurans (PCDFs), biphenyls (PCBs), and polycyclic aromatic hydrocarbons (PAHs) and 2,3,7,8-TCDD equivalents (TEQs) in sediment from the Hyeongsan River, Korea. Environmental Pollution, 132(3), 489-501. http://dx.doi.org/10.1016/j.envpol.2004.05.001

Koh, C. H., Khim, J. S., Villeneuve, D. L., Kannan, K., \& Giesy, J. P. (2006). Characterization of trace organic contaminants in marine sediment from Yeongil Bay, Korea: Dioxin-like and estrogenic activities. Environmental Pollution, 142(1), 48-57. http://dx.doi.org/10.1016/j.envpol.2005.09.006

Koistinen, J., Stenman, O., Haahti, H., Suonperä, M., \& Paasivirta, J. (1997). Polychlorinated diphenyl ethers, dibenzo-p-dioxins, dibenzofurans and biphenyls in seals and sediment from the gulf of finland. Chemosphere, 35(6), 1249-1269. http://dx.doi.org/10.1016/S0045-6535(97)00212-9

Kristensen, E., Mangion, P., Tang, M., Flindt, M. R., Holmer, M., \& Ulomi, S. (2010). Microbial carbon oxidation rates and pathways in sediments of two Tanzanian mangrove forests. Biogeochemistry, 103(1-3), 143-158. http://dx.doi.org/10.1007/s10533-010-9453-2

Kruitwagen, G., Hecht, T., Pratap, H. B., \& Wendelaar-Bonga, S. E. (2005). Changes in morphology and growth of the mudskipper (Periophthalmus argentilineatus) associated with coastal pollution. Marine Biology, 149(2), 201-211. http://dx.doi.org/10.1007/s00227-005-0178-z

Kruitwagen, G., Pratap, H. B., Covaci, A., \& Wendelaar-Bonga, S. E. (2008). Status of pollution in mangrove ecosystems along the coast of Tanzania. Marine Pollution Bulletin, 56(5), 1022-31. http://dx.doi.org/10.1016/j.marpolbul.2008.02.018

Kumar, K. S., Sajwan, K. S., Richardson, J. P., \& Kannan, K. (2008). Contamination profiles of heavy metals, organochlorine pesticides, polycyclic aromatic hydrocarbons and alkylphenols in sediment and oyster collected from marsh/estuarine Savannah GA, USA. Marine Pollution Bulletin, 56(1), 136-49. http://dx.doi.org/10.1016/j.marpolbul.2007.08.011

Lee, Coleman, P., Jones, J. L., Jones, K. C., \& Lohmann, R. (2005). Emission Factors and Importance of PCDD/Fs, PCBs, PCNs, PAHs and PM 10 from the Domestic Burning of Coal and Wood in the U.K. Environmental Science \& Technology, 39(6), 1436-1447. http://dx.doi.org/10.1021/es048745i

Lee, S. J., Kim, J. H., Chang, Y. S., \& Moon, M. H. (2006). Characterization of polychlorinated dibenzo-p-dioxins and dibenzofurans in different particle size fractions of marine sediments. Environmental Pollution, 144(2), 554-61. http://dx.doi.org/10.1016/j.envpol.2006.01.040

Liu, H., Zhang, Q., Cai, Z., Li, A., Wang, Y., \& Jiang, G. (2006). Separation of polybrominated diphenyl ethers, polychlorinated biphenyls, polychlorinated dibenzo-p-dioxins and dibenzo-furans in environmental samples using silica gel and florisil fractionation chromatography. Analytica Chimica Acta, 557(1-2), 314-320. http://dx.doi.org/10.1016/j.aca.2005.10.001

Long, M., Andersen, B. S., Lindh, C. H., Hagmar, L., Giwercman, A., Manicardi, G. C., ... Bonefeld-Jorgensen, E. C. (2006). Dioxin-like activities in serum across European and Inuit populations. Environmental Health, 5(1), 14. http://dx.doi.org/10.1186/1476-069X-5-14

Loomis, D., Browning, S. R., Schenck, A. P., Gregory, E., \& Savitz, D. A. (1997). Cancer mortality among electric utility workers exposed to polychlorinated biphenyls. Occupational and Environmental Medicine, 54(10), 720-728. http://dx.doi.org/10.1136/oem.54.10.720

Machiwa, J. F. (1992). Anthropogenic pollution in the Dar es Salaam harbour area, Tanzania. Marine Pollution Bulletin, 24(11), 562-567. http://dx.doi.org/10.1016/0025-326X(92)90709-F

Maleko, G. C. (2005). Impact of Electricity Services on Microenterprise in Rural Areas in Tanzania Development University of Twente, Enschede.

Manahan, S. A. (2008). Fundamentals of Environmental Chemistry (3rd ed., p. 1264). CRC Press. 
Marchand, C., Lallier-Vergès, E., \& Baltzer, F. (2003). The composition of sedimentary organic matter in relation to the dynamic features of a mangrove-fringed coast in French Guiana. Estuarine, Coastal and Shelf Science, 56(1), 119-130. http://dx.doi.org/10.1016/S0272-7714(02)00134-8

Mbuligwe, S. E., \& Kassenga, G. R. (1997). Automobile air pollution in Dar es Salaam City, Tanzania. Science of The Total Environment, 199(3), 227-235. http://dx.doi.org/10.1016/S0048-9697(97)05461-2

Mihale, M. J., Kishimba, M. A., Baeyens, W., \& Brion, N. (2013). Carbon and Nitrogen dynamics in tropical estuarine mangrove sediments of Mtoni, Tanzania. Unpublished manuscript.

Mkoma, S. (2008). Physico-Chemical Characterisation of Atmospheric Aerosols in Tanzania, with Emphasis on the Carbonaceous Aerosol Components and on Chemical Mass Closure. Retrieved from https://biblio.ugent.be/publication/470145/file/1880861.pdf

Moon, H. B., Choi, M., Choi, H. G., Ok, G., \& Kannan, K. (2009). Historical trends of PCDDs, PCDFs, dioxin-like PCBs and nonylphenols in dated sediment cores from a semi-enclosed bay in Korea: tracking the sources. Chemosphere, 75(5), 565-71. http://dx.doi.org/10.1016/j.chemosphere.2009.01.064

Müller, J. F., Haynes, D., McLachlan, M., Böhme, F., Will, S., Shaw, G. R., ... Connell, D. W. (1999). PCDDs, PCDFs, PCBs and HCB in marine and estuarine sediments from Queensland, Australia. Chemosphere, 39(10), 1707-21. Retrieved from http://www.ncbi.nlm.nih.gov/pubmed/10520488

Müller, Jochen, F., Gaus, C., Prange, J. A., Päpke, O., Poon, K. F., Lam, M. H. W., \& Lam, P. K. (2002). Polychlorinated dibenzo-p-dioxins and polychlorinated dibenzofurans in sediments from Hong Kong. Marine Pollution Bulletin, 45(1-12), 372-8. Retrieved from http://www.ncbi.nlm.nih.gov/pubmed/12398408

Murk, A. (1996). Chemical-Activated Luciferase Gene Expression (CALUX): A Novel In Vitro Bioassay for Ah Receptor Active Compounds in Sediments and Pore Water. Fundamental and Applied Toxicology, 33(1), 149-160. http://dx.doi.org/10.1006/faat.1996.0152

National Bureau for Statistics (NBS). (2003). Tanzania populations and housing census-General report. Retrieved from http://web.archive.org/web/20040313070101/http://www.tanzania.go.tz/census/census/tables.htm

Nieuwoudt, C., Quinn, L. P., Pieters, R., Jordaan, I., Visser, M., Kylin, H., ... Bouwman, H. (2009). Dioxin-like chemicals in soil and sediment from residential and industrial areas in central South Africa. Chemosphere, 76(6), 774-83. http://dx.doi.org/10.1016/j.chemosphere.2009.04.064

Okay, O. S., Karacik, B., Başak, S., Henkelmann, B., Bernhöft, S., \& Schramm, K. W. (2009). PCB and $\mathrm{PCDD} / \mathrm{F}$ in sediments and mussels of the Istanbul strait (Turkey). Chemosphere, 76(2), 159-66. http://dx.doi.org/10.1016/j.chemosphere.2009.03.051

Pan, J., Yang, Y., Geng, C., Yeung, L. W. Y., Cao, X., \& Dai, T. (2010). Polychlorinated biphenyls, polychlorinated dibenzo-p-dioxins and dibenzofurans in marine and lacustrine sediments from the Shandong Peninsula, China. Journal of Hazardous Materials, 176(1-3), 274-9. http://dx.doi.org/10.1016/j.jhazmat.2009.11.024

Peri-urban mangrove forests as filters and potential phytoremediators of domestic sewage in east Africa (PUMPSEA). (2007). Peri-urban mangrove forests as filters and potential phytoremediators of domestic sewage in East Africa (2007). Distribution and fate of heavy metals and indicator pathogens in sewage exposed mangroves, Project No. INCO - CT2004 - 510863.

Pieters, R. (2007). An assessment of dioxins, dibenzofurans and PCBs in the sediments of selected freshwater bodies and estuaries in South Africa. North-West University, Potchefstroom Campus.

Roots, O., Henkelmann, B., \& Schramm, K. W. (2004). Concentrations of polychlorinated dibenzo-p-dioxins and polychlorinated dibenzofurans in soil in the vicinity of a landfill. Chemosphere, 57(5), 337-42. http://dx.doi.org/10.1016/j.chemosphere.2004.06.012

Roy, S., Mysior, P., \& Brzezinski, R. (2002). Comparison of dioxin and furan TEQ determination in contaminated soil using chemical, micro-EROD, and immunoassay analysis. Chemosphere, 48(8), 833-842. http://dx.doi.org/10.1016/S0045-6535(02)00129-7

Ryoo, K. S., Ko, S.-O., Hong, Y. P., Choi, J. H., Cho, S., Kim, Y., \& Bae, Y. J. (2005). Levels of PCDDs and PCDFs in Korean river sediments and their detection by biomarkers. Chemosphere, 61(3), 323-31. http://dx.doi.org/10.1016/j.chemosphere.2005.02.093 
Sanctorum, H., Elskens, M., \& Baeyens, W. (2007). Bioassay (CALUX) measurements of 2,3,7,8-TCDD and PCB 126: interference effects. Talanta, 73(1), 185-8. http://dx.doi.org/10.1016/j.talanta.2007.03.009

Sanctorum, H., Windal, I., Hanot, V., Goeyens, L., \& Baeyens, W. (2007). Dioxin and dioxin-like activity in sediments of the Belgian coastal area (Southern North Sea). Archives of Environmental Contamination and Toxicology, 52(3), 317-25. http://dx.doi.org/10.1007/s00244-006-0063-x

Schecter, A. J., Sheu, S. U., Birnbaum, L. S., Devito, M. J., Denison, M. S., \& Päpke, O. (1999). A comparison and discussion of two differing methods of measuring dioxin-like compounds: gas chromatography-mass spectrometry and the CALUX bioassay-implications for health studies. Organohalogen Compounds, 40, 247-250.

Schroijen, C., Windal, I., Goeyens, L., \& Baeyens, W. (2004). Study of the interference problems of dioxin-like chemicals with the bio-analytical method CALUX. Talanta, 63(5), 1261-8. http://dx.doi.org/10.1016/j.talanta.2004.05.036

Shen, H., Han, J., Tie, X., Xu, W., Ren, Y., \& Ye, C. (2009). Polychlorinated dibenzo-p-dioxins/furans and polychlorinated biphenyls in human adipose tissue from Zhejiang Province, China. Chemosphere, 74(3), 384-8. http://dx.doi.org/10.1016/j.chemosphere.2008.09.094

Smith, A. H., \& Lopipero, P. (2001). Evaluation of the toxicity of dioxins and dioxin-like PCBs: A health risk appraisal for the New Zealand population: A report to the New Zealand Ministry for the Environment (pp. 17-101).

Song, M., Jiang, Q., Xu, Y., Liu, H., Lam, P. K. S., O’Toole, D. K., ... Jiang, G. B. (2006). AhR-active compounds in sediments of the Haihe and Dagu Rivers, China. Chemosphere, 63(7), 1222-30. http://dx.doi.org/10.1016/j.chemosphere.2005.08.065

Srogi, K. (2007). Levels and congener distributions of PCDDs, PCDFs and dioxin-like PCBs in environmental and human samples: a review. Environmental Chemistry Letters, 6(1), 1-28. http://dx.doi.org/10.1007/s10311-007-0105-2

Taylor, M., Ravilious, C., \& Green, E. P. (2003). Mangroves of East Africa-UNEP (p. 28).

Terauchi, H., Takahashi, S., Lam, P. K. S., Min, B. Y., \& Tanabe, S. (2009). Polybrominated, polychlorinated and monobromo-polychlorinated dibenzo-p-dioxins/dibenzofurans and dioxin-like polychlorinated biphenyls in marine surface sediments from Hong Kong and Korea. Environmental Pollution, 157(3), 724-30. http://dx.doi.org/10.1016/j.envpol.2008.11.028

United States Environmental protection Agency (USEPA). (2001). Methods for Collection, Storage and Manipulation of Sediments for Chemical and Toxicological Analyses-Technical Manual, (EPA-823-B-01-002 October 2001), 208.

United States Environmental protection Agency (USEPA). (2008). Method 4435 for Toxic Equivalents (TEQs) determinations for dioxin-like chemical activity with the CALUX bioassay. Retrieved from http://www.epa.gov/osw/hazard/testmethods/pdfs/4435.pdf

Van Camp, M., Mjemah, I. C., Al Farrah, N., \& Walraevens, K. (2013). Modeling approaches and strategies for data-scarce aquifers: example of the Dar es Salaam aquifer in Tanzania. Hydrogeology Journal, 21(2), 341-356. http://dx.doi.org/10.1007/s10040-012-0908-5

Van Langenhove, K., Croes, K., Denison, M. S., Elskens, M., \& Baeyens, W. (2011). The CALUX bio-assay: analytical comparison between mouse hepatoma cell lines with a low (H1L6.1c3) and high (H1L7.5c1) number of dioxin response elements. Talanta, 85(4), 2039-46. http://dx.doi.org/10.1016/j.talanta.2011.07.042

Van Overmeire, I., Van Loco, J., Roos, P., Carbonnelle, S., \& Goeyens, L. (2004). Interpretation of CALUX results in view of the EU maximal TEQ level in milk. Talanta, 63(5), 1241-7. http://dx.doi.org/10.1016/j.talanta.2004.05.034

Wang, H., He, M., Lin, C., Quan, X., Guo, W., \& Yang, Z. (2007). Monitoring and assessment of persistent organochlorine residues in sediments from the Daliaohe River watershed, northeast of China. Environmental Monitoring and Assessment, 133(1-3), 231-42. http://dx.doi.org/10.1007/s10661-006-9576-z

Wong, H. L., Giesy, J. P., Siu, W. H. L., \& Lam, P. K. S. (2005). Estrogenic and dioxin-like activities and cytotoxicity of sediments and biota from Hong Kong mudflats. Archives of Environmental Contamination and Toxicology, 48(4), 575-86. http://dx.doi.org/10.1007/s00244-004-0166-1 
Yang, Z., Shen, Z., Gao, F., Tang, Z., \& Niu, J. (2009). Occurrence and possible sources of polychlorinated biphenyls in surface sediments from the Wuhan reach of the Yangtze River, China. Chemosphere, 74(11), 1522-30. http://dx.doi.org/10.1016/j.chemosphere.2008.11.024

Yoo, H., Khim, J. S., \& Giesy, J. P. (2006). Receptor-mediated in vitro bioassay for characterization of Ah-R-active compounds and activities in sediment from Korea. Chemosphere, 62(8), 1261-71. http://dx.doi.org/10.1016/j.chemosphere.2005.07.007

Zhang, H., Zhao, X., Ni, Y., Lu, X., Chen, J., Su, F., ... Zhang, X. (2010). PCDD/Fs and PCBs in sediments of the Liaohe River, China: levels, distribution, and possible sources. Chemosphere, 79(7), $754-62$. http://dx.doi.org/10.1016/j.chemosphere.2010.02.039

Zhao, L., Hou, H., Zhou, Y., Xue, N., Li, H., \& Li, F. (2010). Distribution and ecological risk of polychlorinated biphenyls and organochlorine pesticides in surficial sediments from Haihe River and Haihe Estuary Area, China. Chemosphere, 78(10), 1285-93. http://dx.doi.org/10.1016/j.chemosphere.2009.12.007 